\title{
Aminofluorination of 2-alkynylanilines: a Au-catalyzed entry to fluorinated indoles
}

\author{
Antonio Arcadi ${ }^{* 1}$, Emanuela Pietropaolo ${ }^{1}$, Antonello Alvino ${ }^{2}$ \\ and Véronique Michelet ${ }^{*} 3$
}

\section{Full Research Paper}

\section{Address:}

1'Dipartimento di Scienze Fisiche e Chimiche, Università di L'Aquila, Via Vetoio- 67010 Coppito (AQ), Italy, ${ }^{2}$ Dipartimento di Chimica, Sapienza, Università di Roma, P. le A. Moro 5, Roma, Italy and ${ }^{3}$ Institut de Recherche de Chimie Paris, UMR 8247, Ecole Nationale Supérieure de Chimie de Paris, Chimie ParisTech, 11 rue $P$. et $M$. Curie, F-75231 Paris Cedex 05, France

\section{Email:}

Antonio Arcadi* - arcadi@univaq.it; Véronique Michelet ${ }^{*}$ -

veronique-michelet@chimie-paristech.fr

* Corresponding author

Keywords:

2-alkynylanilines; fluorination; gold catalysis; indoles; tandem reactions

\author{
Beilstein J. Org. Chem. 2014, 10, 449-458. \\ doi:10.3762/bjoc. 10.42 \\ Received: 05 October 2013 \\ Accepted: 12 February 2014 \\ Published: 20 February 2014 \\ This article is part of the Thematic Series "Gold catalysis for organic \\ synthesis II". \\ Guest Editor: F. D. Toste \\ (C) 2014 Arcadi et al; licensee Beilstein-Institut. \\ License and terms: see end of document.
}

\begin{abstract}
The scope and limitations of gold-catalyzed tandem cycloisomerization/fluorination reactions of unprotected 2-alkynylanilines to have access to 3,3-difluoro-2-aryl-3H-indoles and 3-fluoro-2-arylindoles are described. An unprecedented aminoauration/oxidation/ fluorination cascade reaction of 2-alkynylanilines bearing a linear alkyl group on the terminal triple bond is reported.
\end{abstract}

\section{Introduction}

Introducing fluorine atoms into organic molecules still faces challenges in organic synthesis [1]. Organofluorine compounds found growing use in various areas including pharmaceuticals, agrochemicals, and materials [2]. A significant proportion of pharmaceuticals are fluorinated derivatives because the inclusion of fluorine into organic compounds has been shown to improve properties such as solubility, bioavailability and metabolic stability, which are of great importance for the development of a large number of viable drug candidates [3]. Finding original methodologies for the selective preparation of fluorinated heterocyclic compounds is therefore still highly chal- lenging $[4,5]$. The variation of the indole structure has been a field of high interest for a long time, considering the importance of this skeleton as a ubiquitous skeleton of pharmaceuticals and bioactive natural products [6-11]. The synthesis of 3-substiuted 3-fluorooxindoles has been described in the presence of Selectfluor as a commercial source of $\mathrm{F}^{+}$, starting from 3 -substituted indoles, in acetonitrile/water. These derivatives have been used as key adducts for the indole biosynthesis mechanism as well as synthetic target for the development of novel medicinal agents [12]. Recently, 7-fluoroindole has been proposed as a potential candidate for the use in an antivirulence 
approach against persistent Pseudomonas aeruginosa infections [13]. Fluorine introduction in the benzene moiety of respective indoles was accomplished through a variety of methods [14]. 4-Fluoroindole derivatives have been prepared through nucleophilic attack on intermediate 4-indolediazonium salts [15]. The regioselective fluorination of the benzene ring of indole to give the important neurochemicals 4-fluoroserotonin and 4-fluoromelatonin was accomplished by means of a lithiation/fluorination sequence [16]. The validity of this latter strategy was also demonstrated for the fluorination at the 2-position of $\mathrm{N}$-protected indoles by electrophilic fluorinating agents. Our literature search revealed that the access to C-3 fluorinated indole derivatives was less investigated. Fluorination of trialkylstannylindole derivatives with cesium fluoroxysulfate or Selectfluor was investigated for the synthesis of the corresponding 3-fluoroindoles [17]. A borane-tetrahydrofuran complex has been used to study the reduction of 3,3-difluoro-2-oxindoles to give the corresponding 3,3-difluoroindoines when electronwithdrawing groups were present as substituents in the benzene nucleus. The 3,3-difluoro-2-oxindoles were prepared by the reaction of appropriately substituted isatin derivatives with DAST [18]. Anodic fluorination of various $N$-acetyl-3-substituted indoles was successfully carried out to provide trans-2,3difluoro-2,3-dihydroindoles which upon treatment with a base gave monofluoroindole derivatives or monofluoro-3 $H$-indoles depending on the substituents at the 3-position [19]. More recently, the indole ring was difluorinated highly regioselectively at the C-3 carbon site with Selectfluor [20]. The C-3 monofluorinated indole derivatives were supposed to serve as intermediates in the transformation and can be isolated under suitable reaction conditions [21]. We envisaged that the aminofluorination of the ready available $o$-alkynylaniline derivatives should provide a viable alternative to the desired C-3 fluorinated indoles. Catalytic aminofluorination of alkenes and alkynes is receiving growing attention as efficient way to construct fluorinated heterocycles [22,23]. In particular, Au-catalyzed fluorination strategies by using Selectfluor as an electrophilic source of fluorine [24-31] can provide a powerful tool for building up nitrogen heterocycle derivatives. Fluorinated pyrrolidines [32] and fluorinated pyrazoles [33] have been synthesized from $1, \omega-\mathrm{N}$-protected aminoalkynes and alkynyl phenylhydrazones, respectively. Propargyl amidines were converted into 5-fluoromethylimidazoles in the presence of
Selectfluor under gold(I) catalysis [34-36] through a cascade cyclization/fluorination process [37]. Following our previous work on gold catalysts (Scheme 1) [38], we wish to report herein a comprehensive study on gold-catalyzed tandem cycloisomerization/fluorination reactions to access 3,3-difluoro-2aryl-3H-indoles and 3-fluoro-2-arylindoles, putting the stress on the scope and limitations of such systems.

\section{Results and Discussion Optimization of the catalytic system}

The substrate 2-\{[4-(methoxy)phenyl] ethynyl $\}$ aniline (1a) was selected as a model substrate and was subjected to various conditions in the presence of Selectfluor as the electrophilic fluorine source. The results are compiled in Table 1. When the reaction of 1a was carried out at room temperature with an excess of Selectfluor and water in $\mathrm{CH}_{3} \mathrm{CN}$ in the absence of any catalyst (Table 1, entry 1), no desired fluorinated indole was detected and degradation of the starting $\mathrm{N}$-unprotected 2-alkynylaniline 1a was observed, which excludes a fluorocyclization according to a direct electrophilic process [39]. When the same reaction was performed in the presence of [bis(trifluoromethanesulfonyl)imidate](triphenylphosphine)gold (I) catalyst [40] (5 mol \%), the formation of the difluorinated $3 H$-indole 2a was observed although in low overall yield (Table 1, entry 2 ). No traces of $\mathrm{C}-\mathrm{C}$ bond formation, a competitive pathway in the presence of gold catalysts and Selectfluor [41-43] were observed. The yield of $\mathbf{2 a}$ was increased to $35 \%$ when the reaction was carried out in the presence of $10 \mathrm{~mol} \%$ of the gold catalyst (Table 1, entry 3 ). Various other parameters were modified to increase the reaction efficiency. The amount of water played a determinant role in $\mathrm{CH}_{3} \mathrm{CN}$ as the reaction medium (Table 1, entries 3-5). The presence of water is considered important both as a reagent and for helping the dissolution of Selectfluor in $\mathrm{CH}_{3} \mathrm{CN}$. One of the most notable limitations on the use of Selectfluor is indeed its relative insolubility in commonly used organic solvents. Even in $\mathrm{MeCN}$, the solvent of choice for many reactions with Selectfluor, its solubility is undesirably low and presents a limitation in its overall use as a fluorinating agent. The presence of a minimal amount of water has previously been reported to increase the yield of fluorination in the 5-position of mono- and nonbrominated 2-acylpyrroles with Selectfluor under microwave conditions [44]. The presence of larger amounts of water may nevertheless

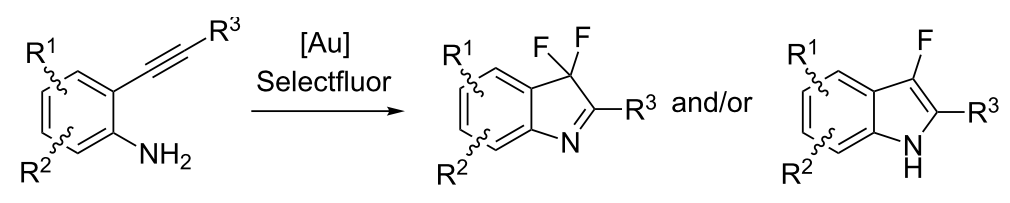


Table 1: Cycloisomerization/fluorination of 2-\{[4-(methoxy)phenyl]ethynyl\}aniline (1a).

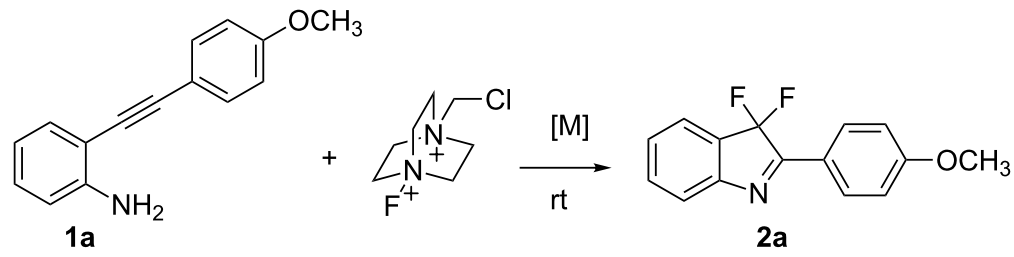

\begin{tabular}{|c|c|c|c|c|c|}
\hline Entry & [M] $10 \mathrm{~mol} \%$ & Selectfluor (equiv) & $\begin{array}{l}\text { solvent } \\
\mathrm{H}_{2} \mathrm{O} \text { (x equiv) }\end{array}$ & $t[\mathrm{~h}]$ & Yield $[\%]^{a}$ \\
\hline 1 & - & 2.5 & $\mathrm{CH}_{3} \mathrm{CN}(10)$ & 3 & - \\
\hline 2 & $\mathrm{Ph}_{3} \mathrm{PAuNTf}{ }_{2}{ }^{\mathrm{b}}$ & 2.5 & $\mathrm{CH}_{3} \mathrm{CN}(10)$ & 3 & 14 \\
\hline 3 & $\mathrm{Ph}_{3} \mathrm{PAuNTf}_{2}$ & 2.5 & $\mathrm{CH}_{3} \mathrm{CN}(10)$ & 3 & 35 \\
\hline 4 & $\mathrm{Ph}_{3} \mathrm{PAuNTf}_{2}$ & 2.5 & $\mathrm{CH}_{3} \mathrm{CN}(50)$ & 3 & 40 \\
\hline 5 & $\mathrm{Ph}_{3} \mathrm{PAuNTf}_{2}$ & 2.5 & $\mathrm{CH}_{3} \mathrm{CN}(100)$ & 3 & 17 \\
\hline 6 & $\mathrm{Ph}_{3} \mathrm{PAuNTf}_{2}$ & 1 & $\mathrm{CH}_{3} \mathrm{CN}(100)$ & 21 & 37 \\
\hline 7 & $\mathrm{Ph}_{3} \mathrm{PAuNTf}_{2}$ & 2.5 & $\mathrm{EtOH}(0)$ & 24 & 49 \\
\hline 8 & $\mathrm{Ph}_{3} \mathrm{PAuNTf}_{2}$ & 2 & $\mathrm{EtOH}(100)$ & 1.5 & 54 \\
\hline 9 & $\mathrm{Ph}_{3} \mathrm{PAuNTf}_{2}$ & 3 & EtOH (100) & 1.5 & 75 \\
\hline 10 & $\mathrm{Ph}_{3} \mathrm{PAuNTf}_{2}$ & 2 & $\mathrm{EtOH}(50)$ & 24 & 17 \\
\hline 11 & $\mathrm{Ph}_{3} \mathrm{PAuNTf}_{2}$ & 2 & 1,4-dioxane (100) & 2 & 0 \\
\hline 12 & $\mathrm{Ph}_{3} \mathrm{PAuNTf}_{2}$ & 3 & acetone (100) & 2 & 0 \\
\hline 13 & $\mathrm{AuCl}$ & 3 & EtOH (100) & 2 & 56 \\
\hline 14 & $\mathrm{AuCl}_{3}$ & 3 & EtOH (100) & 2 & 38 \\
\hline 15 & $\mathrm{NaAuCl}_{4}$ & 3 & EtOH (100) & 0.25 & 45 \\
\hline 16 & $\mathrm{KAuCl}_{4}$ & 3 & $\mathrm{EtOH}(100)$ & 2 & 53 \\
\hline 17 & $\mathrm{PdCl}_{2}$ & 3 & EtOH (100) & 2 & 0 \\
\hline 18 & $\mathrm{PtCl}_{2}$ & 3 & $\mathrm{EtOH}(100)$ & 2 & 0 \\
\hline 19 & $\mathrm{CuCl}_{2} \cdot 2 \mathrm{H}_{2} \mathrm{O}$ & 3 & EtOH (100) & 2 & 0 \\
\hline 20 & $\mathrm{RuCl}_{3} \cdot 2 \mathrm{H}_{2} \mathrm{O}$ & 3 & $\mathrm{EtOH}(100)$ & 2 & 0 \\
\hline 21 & $\mathrm{AgNTf}_{2}$ & 3 & EtOH (100) & 2 & 0 \\
\hline
\end{tabular}

asolated yield. ${ }^{\mathrm{b}} 5 \mathrm{~mol} \%$.

speed up the protodeauration of the indolylgold species derived from the gold-catalyzed aminoauration of $\mathbf{1 a}$ to give the 2-substituted indole [39]. The reaction of $\mathbf{1 a}$ was also evaluated in various solvents and proceeded nicely in $\mathrm{EtOH}$ compared to MeCN, 1,4-dioxane, and acetone (Table 1, entries 9, 11, and 12).

In the presence of EtOH, we were pleased to find that the desired adduct $2 \mathrm{a}$ was isolated in $75 \%$ yield (Table 1 , entry 9 ). The addition of $\mathrm{NaHCO}_{3}[20,33]$ as a base to the reaction mixture failed to give 2a, whereas it was successful for the preparation of fluorinated pyrazole, via the gold(I)-catalyzed tandem aminofluorination of 1-phenyl-2-(4-phenylbut-3-yn-2ylidene)hydrazine. Other gold catalysts such as gold(III) species presented interesting results for the reaction beside lower yield than gold(I) catalyst (Table 1, entries 14-16 vs entries 9 and 13). Other transition metal catalysts such as $\mathrm{PdCl}_{2}, \mathrm{PtCl}_{2}$, $\mathrm{CuCl}_{2} \cdot 2 \mathrm{H}_{2} \mathrm{O}, \mathrm{RuCl}_{3} \cdot 2 \mathrm{H}_{2} \mathrm{O}$, or AgNTf ${ }_{2}$ were also tested, but did not give the desired difluorinated $3 H$-indole (Table 1 , entries 17-21). We selected the $\mathrm{PPh}_{3} \mathrm{AuNTf}_{2}$ catalyst as a highly efficient complex and the cheaper $\mathrm{NaAuCl}_{4} \cdot 2 \mathrm{H}_{2} \mathrm{O}$ catalyst and decided to confront their reactivity to various substrates.

We selected some derivatives $(\mathbf{1 a}-\mathbf{e}, \mathbf{1 g}, \mathbf{1 i}$ and $\mathbf{4 a}, \mathbf{b})$ from literature $[38,39,45-51]$ and synthesized them together with new functionalized 2-alkynylanilines to evaluate the efficiency of the gold catalytic system.

\section{Scope and limitations of the catalytic system}

The prepared 2-substituted anilines were then engaged in the cycloisomerization/fluorination process in the presence of the $\mathrm{Au}(\mathrm{I})$ cationic catalyst or the $\mathrm{Au}(\mathrm{III})$ catalyst (Table 2, conditions $\mathrm{A}$ and $\mathrm{B}$ ). The anilines $\mathbf{1 b}-\mathbf{1} \mathbf{f}$ were subjected to conditions $\mathrm{A}$ and $\mathrm{B}$ at room temperature or refluxing ethanol. Under conditions $\mathrm{A}$, the $\mathrm{NaAuCl}_{4} \cdot 2 \mathrm{H}_{2} \mathrm{O}$ catalyst operated smoothly and Selectfluor ( 3 equiv) was added when full conversion of the 
Table 2: Cycloisomerization/fluorination reaction of 2-substituted anilines.

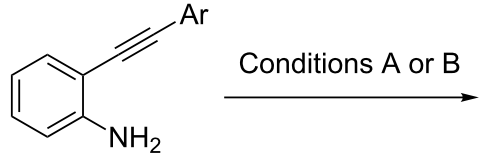

1b-g<smiles>FC1(F)C(Br)=Nc2ccccc21</smiles>

$2 b-g$
Conditions A: a) $5 \mathrm{~mol} \% \mathrm{NaAuCl}_{4} \cdot 2 \mathrm{H}_{2} \mathrm{O}$,

$\mathrm{EtOH} / \mathrm{H}_{2} \mathrm{O}$, rt or reflux. b) Selectfluor (3 equiv)

Conditions B: $10 \mathrm{~mol} \% \mathrm{PPh}_{3} \mathrm{AuNTf}_{2}$, Selectfluor

(3 equiv), $\mathrm{EtOH} / \mathrm{H}_{2} \mathrm{O}$, rt or reflux

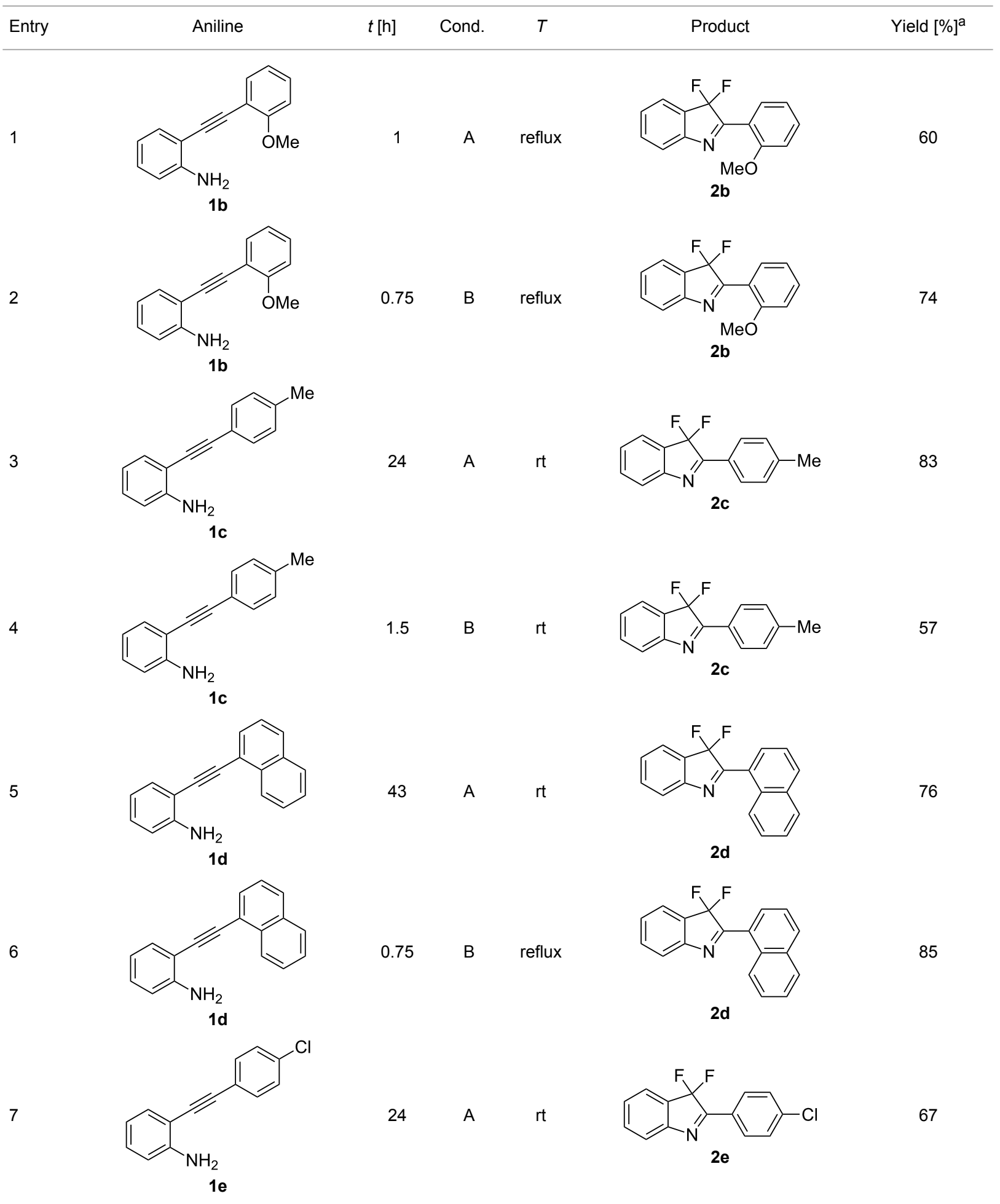


Table 2: Cycloisomerization/fluorination reaction of 2-substituted anilines. (continued)

8<smiles>Nc1ccccc1C#Cc1ccc(Cl)cc1</smiles><smiles>Nc1ccccc1C#Cc1cn[nH]c1</smiles><smiles>Nc1ccccc1C#Cc1cn[nH]c1</smiles>

$1 f$<smiles>Nc1ccccc1C#Cc1ccccn1</smiles>

$1 \mathrm{~g}$<smiles>Nc1ccccc1C#Cc1ccccn1</smiles>

2

B

reflux

3

A

reflux

2

B

reflux

A

reflux

B

reflux<smiles></smiles>
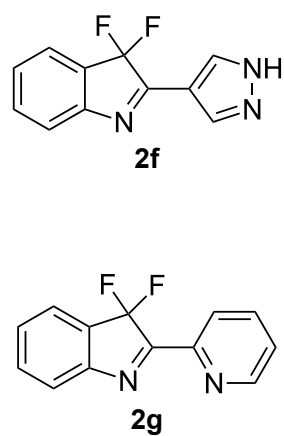<smiles>FC1(F)C(c2ccc(Cl)cc2)=Nc2ccccc21</smiles>

$2 e$

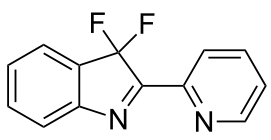

$2 \mathrm{~g}$

$1 \mathrm{~g}$

alsolated yield.

gold(III)-catalyzed cyclization of $\mathbf{1}$ was observed. The use of the cationic $\mathrm{PPh}_{3} \mathrm{AuNTf}_{2}$ complex allowed in situ addition of Selectfluor. Both catalytic systems were efficient and depending on the substrate higher yields were obtained either in the presence of the $\mathrm{Au}(\mathrm{III})$ or $\mathrm{Au}(\mathrm{I})$ catalyst. The difluoro derivatives $\mathbf{2 b}-\mathbf{f}$ were isolated in moderate to very good yields. In the case of substrates $\mathbf{2 b}$ or $\mathbf{2 d}$ bearing an $o$-substituent group in the aryl moiety, better yields of these desired cyclized and functionalized derivatives were observed in ethanol at reflux (Table 2, entries $1 / 2$ and comparison of 5 vs 6 ). The reaction conditions were compatible with a halogen substituent such as in $\mathbf{2 e}$ (Table 2, entries 7 and 8), which was obtained in up to $67 \%$ yield. Gratifyingly the presence of 4-substituted $1 H$-pyrazole allowed the clean formation of the corresponding difluoroadduct $\mathbf{2} \mathbf{f}$ in good isolated yields (Table 2, entries 9 and 10). One limitation was found when 2-substituted pyridylalkyne $\mathbf{1 g}$ was subjected to conditions A (Table 2, entry 11). No reaction occurred and the starting material was recovered. A complex reaction mixture was obtained by reacting $1 \mathrm{~g}$ in $\mathrm{EtOH}$ at reflux for $1 \mathrm{~h}$ with an excess of Selectfluor (3 equiv) in the presence of $\mathrm{Ph}_{3} \mathrm{PAuNTf}_{2}$ catalyst (Table 2, entry 12).

The case of aniline $\mathbf{1 h}$ was particularly interesting as it showed that ethanol was not a fully inert solvent (Scheme 2, reaction 1). Indeed, when reacting aniline $\mathbf{1 h}$ substituted with electron-withdrawing groups on both the aniline and the aryl moiety under $\mathrm{Au}(\mathrm{III})$ conditions, the desired product $\mathbf{2 h}$ was accompanied by the hemiaminal difluoroadduct $\mathbf{3 h}$, which was isolated in $56 \%$ yield. The isolated $\mathbf{3 h}$ spontaneously decomposed to give quantitatively $\mathbf{2 h}$. A similar trend was observed in the case of tosyl-protected aniline $\mathbf{4 a}$ (Scheme 2, reaction 2). The reaction of the latter compound led to the formation of difluoro hemiaminal $5 \mathbf{a}$ in $42 \%$ yield. Interestingly a novel derivative $6 \mathbf{a}$ was also isolated in $14 \%$ yield. We also tested the reactivity of 
<smiles>CCC#Cc1cc(Cl)cc(Cl)c1N</smiles>

$1 \mathrm{~h}$ a) $5 \mathrm{~mol} \% \mathrm{NaAuCl}_{4} \cdot 2 \mathrm{H}_{2} \mathrm{O}$ $\mathrm{EtOH} / \mathrm{H}_{2} \mathrm{O}$, reflux, $2 \mathrm{~h}$

b) Selectfluor (3 equiv), $22 \mathrm{~h}$<smiles>CCOC(=O)c1ccc(C2=Nc3c(Cl)cc(Cl)cc3C2(F)F)cc1</smiles>

$2 \mathrm{~h} \quad 12 \%$

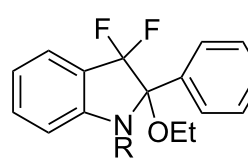

5a $42 \%$

5 b $\quad-$<smiles>[R]OC1(c2ccccc2)Nc2ccccc2C1=O</smiles>

6a $14 \%$

6b -

a) $5 \mathrm{~mol} \% \mathrm{NaAuCl}_{4} \cdot 2 \mathrm{H}_{2} \mathrm{O}$ $\mathrm{EtOH} / \mathrm{H}_{2} \mathrm{O}$, reflux, $3 \mathrm{~h}$

b) Selectfluor (3 equiv), $4 \mathrm{~h}$

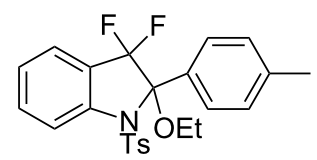

5c $54 \%$

Scheme 2: Synthesis of hemiaminal derivatives.

trifluoroacetyl-protected aniline $\mathbf{4 b}$, but no cyclization occurred and the starting material was recovered. In the case of the tolylsubstituted alkyne $\mathbf{4 c}$, the difluorinated product $\mathbf{5 c}$ was the only isolated derivative in moderate $54 \%$ yield (Scheme 2, reaction 3).

We also envisaged evaluating the influence of the alkynyl substituent of the aniline moiety. For this purpose, the Au(III)catalyzed cycloisomerization/fluorination process was tested on $n$-alkyl-substituted derivative 1i (Scheme 3 ). The reaction conducted at room temperature led to the (E)-2-(1-fluorohexylidene)indolin-3-one (7), whose structure and stereochemistry was confirmed by ${ }^{1} \mathrm{H}$ NMR and NOESY experiments (see
Supporting Information File 1), in 39\% yield. Pleasingly, the monofluoro derivative $8 \mathbf{i}$ was isolated in $25 \%$ yield by conducting the same reaction at $50{ }^{\circ} \mathrm{C}$ and in the presence of a lower amount of Selectfluor.

The mechanism for the formation of 7 (Scheme 4) may imply amino-auration of the alkyne $1 \mathbf{i}$ to generate the indolyl-Au complex I according to the results observed in the tandem aminopalladation/oxidation process of azidoalkynes [52]. Then the $\mathrm{C}-\mathrm{Au}$ bond is oxidized by Selectfluor [53-57] and would give the 2-hexyl-3H-indol-3-one (9). The formation of this latter derivative by the oxidation of 2-hexyl- $1 H$-indole [58-62] or 3-fluoro-2-hexyl-1 $H$-indole (8i) [63] cannot be ruled out. The

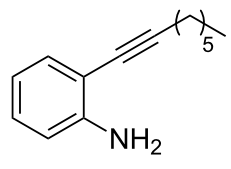

$1 \mathrm{i}$

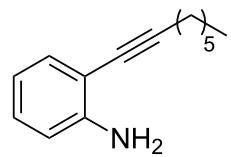

$1 \mathrm{i}$ a) $5 \mathrm{~mol} \% \mathrm{NaAuCl}_{4} \cdot 2 \mathrm{H}_{2} \mathrm{O}$ $\mathrm{EtOH} / \mathrm{H}_{2} \mathrm{O}, \mathrm{rt}, 4 \mathrm{~h}$

b) Selectfluor ( 2.5 equiv) $20 \mathrm{~h}$

a) $5 \mathrm{~mol} \% \mathrm{NaAuCl}_{4} \cdot 2 \mathrm{H}_{2} \mathrm{O}$ $\mathrm{EtOH} / \mathrm{H}_{2} \mathrm{O}, 50{ }^{\circ} \mathrm{C}, 0.5 \mathrm{~h}$

b) Selectfluor (1 equiv) $2.5 \mathrm{~h}$

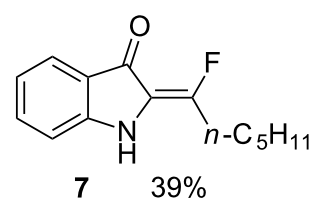

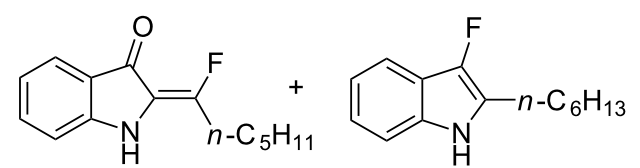

$7 \quad 22 \%$

Scheme 3: Reaction on $n$-hexyl-substituted derivative $\mathbf{1 i}$. 


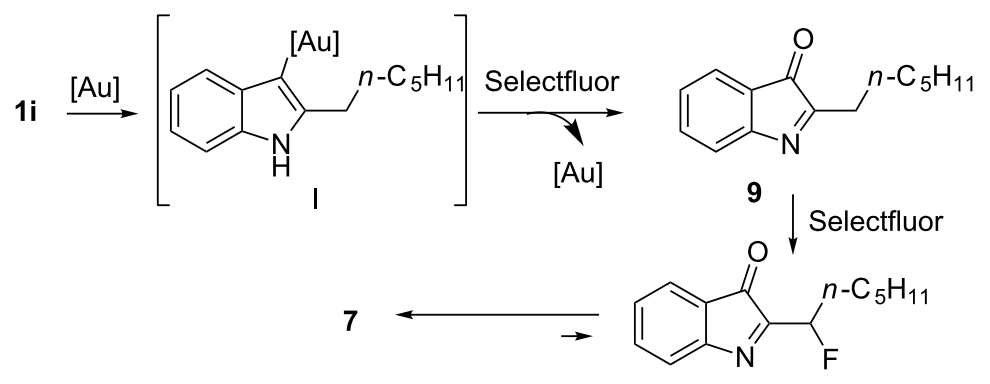

10

Scheme 4: Mechanism rationale for the formation of 7.

following fluorination [64-67] of 9 led to 2-(1-fluorohexyl)-3Hindol-3-one (10), which tautomerizes to accomplish the stereoselective formation of 7 .

Considering the reactivity of anilines $\mathbf{1 a}-\mathbf{1 i}$ in the presence of $\mathrm{NaAuCl}_{4} \cdot \mathrm{H}_{2} \mathrm{O}$ complex in ethanol and the formation of $\mathbf{8}$ in the presence of 1 equivalent of Selectfluor, we decided to modify our initial procedure to selectively prepare 3-fluoro-2-aryl- indoles. We found that the cyclization of various unprotected anilines in acetonitrile followed by one-pot addition of Selectfluor in DMSO allowed the clean formation of monofluorinated derivatives and results are collected in Table 3.

With the optimal reaction conditions in hand, the substrate scope was examined. In the presence of the electron-rich aromatic groups on the terminal triple bond the desired prod-

Table 3: Cycloisomerization/fluorination reaction of 2-alkynyl-substituted anilines.

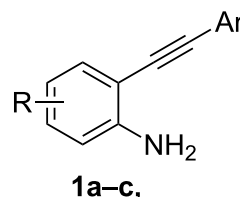

a) $5 \mathrm{~mol} \% \mathrm{NaAuCl}_{4} \cdot 2 \mathrm{H}_{2} \mathrm{O}$ $\mathrm{CH}_{3} \mathrm{CN}, 0^{\circ} \mathrm{C}$

b) Selectfluor (1 equiv) DMSO, $0^{\circ} \mathrm{C}$ to $\mathrm{rt}$

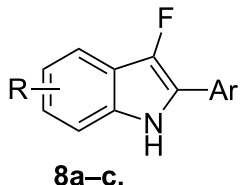

8f, 8i, 8j

Entry Aniline

$1 a$<smiles>COc1ccccc1C#Cc1ccccc1N</smiles>

$1 b$<smiles>Cc1ccc(C#Cc2ccccc2N)cc1</smiles>

$1 \mathrm{c}$<smiles>COc1ccc(-c2[nH]c3ccccc3c2F)cc1</smiles>

$8 a$<smiles>COc1ccccc1-c1[nH]c2ccccc2c1F</smiles>

$8 b$<smiles>Fc1c(-c2ccc(I)cc2)[nH]c2ccccc12</smiles>

41 8c

$1 / 1$$$
8 c
$$ 
Table 3: Cycloisomerization/fluorination reaction of 2-alkynyl-substituted anilines. (continued)

4<smiles>Nc1ccccc1C#Cc1cn[nH]c1</smiles>

$1 f$

5<smiles>CCC#Cc1ccccc1N</smiles>

$1 \mathrm{i}$<smiles>CC#Cc1cc(Cl)cc(Cl)c1N</smiles>

$1 \mathrm{j}$
$0.3 / 1$<smiles>Fc1c(-c2cn[nH]c2)[nH]c2ccccc12</smiles>
$20^{b}$

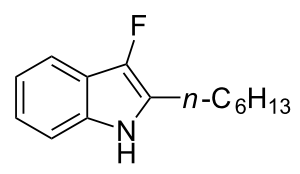

40

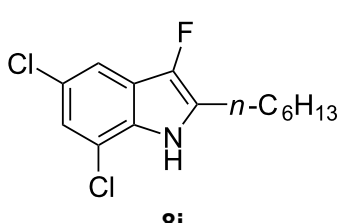

alsolated yield. ${ }^{\mathrm{b}} 40 \%$ of $\mathbf{2} \mathbf{f}$ was also isolated.

ucts were isolated in moderate yields (Table 3, entries 1-3). In the presence of the $1 H$-pyrazolyl moiety the difluorination prevailed over the monofluorination process (Table 3, entry 4). With the 2-alkynylanilines bearing a linear alkyl group on the terminal triple bond, better results were observed in the presence of electron withdrawing groups in the aromatic ring of the aniline framework (Table 3, compare entry 5 with entry 6). It's noteworthy that the preparation of 3-fluoroindoles is quite challenging. Because of overoxidation, the isolation of 3-fluoroindoles from 2-alkynylanilines has been reported to fail to occur [52] using previously developed silver catalysts [68]. In our cases, the fluorination reactions were conducted at $0{ }^{\circ} \mathrm{C}$ to avoid overoxidation processes.

\section{Conclusion}

In conclusion, we have contributed to the development of onepot gold-catalyzed aminofluorination of unprotected 2-alkynylanilines. The combination of a $\mathrm{Au}(\mathrm{I})$ or $\mathrm{Au}(\mathrm{III})$ complex associated to Selectfluor promotes the cycloisomerization/fluorination of non-protected aryl-substituted anilines at room temperature or refluxing ethanol. The reactions were found to be highly substrate- and solvent-dependent as different outcomes occur in ethanol or acetonitrile/DMSO mixture. The functionalized fluorinated indoles were isolated in moderate to very good yields. An unusual aminoauration/oxidation/fluorination cascade reaction was observed with 2-alkynylanilines bearing a linear alkyl group on the terminal triple bond. Further studies are in progress aimed to the selectivity control of the sequential gold-catalyzed oxidative cycloamination process of 2-alkynylanilines.

\section{Supporting Information}

\section{Supporting Information File 1}

Experimental.

[http://www.beilstein-journals.org/bjoc/content/

supplementary/1860-5397-10-42-S1.pdf]

\section{Acknowledgements}

This work was supported by Università dell'Aquila, the Ministère de l'Education et de la Recherche and the Centre National de la Recherche Scientifique (CNRS). Johnson Matthey Inc. is acknowledged for a generous loan of $\mathrm{AuCl}_{3}$, $\mathrm{PdCl}_{2}$ and $\mathrm{PtCl}_{2}$.

\section{References}

1. Liang, T.; Neumann, C. N.; Ritter, T. Angew. Chem., Int. Ed. 2013, 52, 8214-8264. doi:10.1002/anie.201206566

And references cited therein.

2. Kirsch, P. Modern Fluoroorganic Chemistry: Synthesis, Reactivity, Applications, 2nd ed.; Wiley-VCH: Weinheim, 2013.

3. Bright, T. V.; Dalton, F.; Elder, V. L.; Murphy, C. D.; O'Connor, N. K.; Sandford, G. Org. Biomol. Chem. 2013, 11, 1135-1142. doi:10.1039/c2ob27140k

4. Liu, G. Org. Biomol. Chem. 2012, 10, 6243-6248. doi:10.1039/c2ob25702e

5. Hollingworth, C.; Gouverneur, V. Chem. Commun. 2012, 48, 2929-2942. doi:10.1039/c2cc16158c

6. Knepper, K.; Vanderheiden, S.; Bräse, S. Beilstein J. Org. Chem. 2012, 8, 1191-1199. doi:10.3762/bjoc.8.132 
7. Karchava, A. V.; Melkonyan, F. S.; Yurovskaya, M. A. Chem. Heterocycl. Compd. 2012, 48, 391-407. doi:10.1007/s10593-012-1006-2

8. Platon, M.; Amardeil, R.; Djakovitch, L.; Hierso, J.-C. Chem. Soc. Rev. 2012, 41, 3929-3968. doi:10.1039/c2cs15350e

9. Vicente, R. Org. Biomol. Chem. 2011, 9, 6469-6480. doi:10.1039/c1ob05750b

10. Cacchi, S.; Fabrizi, G. Chem. Rev. 2011, 111, PR215-PR283. doi:10.1021/cr100403z

11. Taber, D. F.; Tirunahari, P. K. Tetrahedron 2011, 67, 7195-7210. doi:10.1016/j.tet.2011.06.040

12. Seki, T.; Fujiwara, T.; Takeuchi, Y. J. Fluorine Chem. 2011, 132, 181-185. doi:10.1016/j.jfluchem.2010.12.014

13. Lee, J.-H.; Kim, Y.-G.; Cho, M. H.; Kim, J.-A.; Lee, J. FEMS Microbiol. Lett. 2012, 329, 36-44. doi:10.1111/j.1574-6968.2012.02500.x

14. Politanskaya, L. V.; Chuikov, I. P.; Shteingarts, V. D. Tetrahedron 2013, 69, 8477-8486. doi:10.1016/j.tet.2013.07.037 And references cited therein.

15. Somei, M.; Kizu, K.; Kunimoto, M.; Yamada, F. Chem. Pharm. Bull. 1985, 33, 3696-3708. doi:10.1248/cpb.33.3696

16. Hayakawa, Y.; Singh, M.; Shibata, N.; Takeuchi, Y.; Kirk, K. L. J. Fluorine Chem. 1999, 97, 161-164. doi:10.1016/S0022-1139(99)00044-5

17. Hodson, H. F.; Madge, D. J.; Slawin, A. N. Z.; Widdowson, D. A.; Williams, D. J. Tetrahedron 1994, 50, 1899-1906. doi:10.1016/S0040-4020(01)80862-0

18. Torres, J. C.; Garden, S. J.; Pinto, A. C.; da Silva, F. S. Q.; Boechat, N. Tetrahedron 1999, 55, 1881-1892. doi:10.1016/S0040-4020(98)01229-0

19. Yin, B.; Wang, L.; Inagi, S.; Fuchigami, T. Tetrahedron 2010, 66, 6820-6825. doi:10.1016/j.tet.2010.06.063

20. Lin, R.; Ding, S.; Shi, Z.; Jiao, N. Org. Lett. 2011, 13, 4498-4501. doi:10.1021/ol201896p

21. Mccomas, C. C.; Liverton, N. J.; Habermann, J.; Koch, U.; Narjes, F.; Li, P.; Peng, X.; Soll, R.; Wu, H.; Palani, A.; He, S.; Dai, X.; Liu, H.; Lai, Z.; London, C.; Xiao, D.; Zorn, N.; Nargund, R. Tetracyclic heterocycle compounds and methods of use thereof for the treatment of viral diseases. WO Pat. Appl. WO2013033971 A1, March 14, 2013.

22. Chemler, S. R.; Bovino, M. T. ACS Catal. 2013, 3, 1076-1091. doi:10.1021/cs400138b

23. Li, Z.; Song, L.; Li, C. J. Am. Chem. Soc. 2013, 135, 4640-4643. doi:10.1021/ja400124t

24. Liu, Y.; Zhu, J.; Qian, J.; Xu, Z. J. Org. Chem. 2012, 77, 5411-5417. doi:10.1021/jo3006528

25. de Haro, T.; Nevado, C. Chem. Commun. 2011, 47, 248-249. doi:10.1039/c002679d

26. Hofer, M.; Nevado, C. Eur. J. Inorg. Chem. 2012, 1338-1341. doi:10.1002/ejic.201100956

27. Wang, W.; Jasinski, J.; Hammond, G. B.; Xu, B. Angew. Chem., Int. Ed. 2010, 49, 7247-7252. doi:10.1002/anie.201003593

28. de Haro, T.; Nevado, C. Adv. Synth. Catal. 2010, 352, 2767-2772. doi:10.1002/adsc.201000559

29. Hopkinson, M. N.; Giuffredi, G. T.; Gee, A. D.; Gouverneur, V. Synlett 2010, 2737-2742. doi:10.1055/s-0030-1258992

30. Schuler, M.; Silva, F.; Bobbio, C.; Tessier, A.; Gouverneur, V. Angew. Chem., Int. Ed. 2008, 47, 7927-7930. doi:10.1002/anie.200802162
31. Mankad, N. P.; Toste, F. D. Chem. Sci. 2012, 3, 72-76. doi:10.1039/c1sc00515d

32. Simonneau, A.; Garcia, P.; Goddard, J.-P.; Mouriès-Mansuy, V.; Malacria, M.; Fensterbank, L. Beilstein J. Org. Chem. 2011, 7, 1379-1386. doi:10.3762/bjoc.7.162

33. Qian, J.; Liu, Y.; Zhu, J.; Jiang, B.; Xu, Z. Org. Lett. 2011, 13, 4220-4223. doi:10.1021/ol201555z

34. Gorin, D. J.; Sherry, B. D.; Toste, F. D. Chem. Rev. 2008, 108, 3351-3378. doi:10.1021/cr068430g

35. Fürstner, A.; Davies, P. W. Angew. Chem., Int. Ed. 2007, 46, 3410-3449. doi:10.1002/anie.200604335

36. Hashmi, A. S. K.; Hutchings, G. J. Angew. Chem., Int. Ed. 2006, 45, 7896-7936. doi:10.1002/anie.200602454

37. Li, S.; Li, Z.; Yuan, Y.; Li, Y.; Zhang, L.; Wu, Y. Chem.-Eur. J. 2013, 19, 1496-1501. doi:10.1002/chem.201202402

38. Arcadi, A.; Pietropaolo, E.; Alvino, A.; Michelet, V. Org. Lett. 2013, 15, 2766-2769. doi:10.1021/ol401098b

39. Arcadi, A.; Bianchi, G.; Marinelli, F. Synthesis 2004, 610-619. doi:10.1055/s-2004-815947

40. Mézailles, N.; Ricard, L.; Gagosz, F. Org. Lett. 2005, 7, 4133-4136. doi:10.1021/ol0515917

41. Hashmi, A. S. K.; Ramamurthi, T. D.; Rominger, F. J. Organomet. Chem. 2009, 694, 592-597. doi:10.1016/j.jorganchem.2008.11.054

42. Zhang, G.; Peng, Y.; Cui, L.; Zhang, L. Angew. Chem., Int. Ed. 2009, 48, 3112-3115. doi:10.1002/anie.200900585

43. Mankad, M. P.; Toste, F. D. J. Am. Chem. Soc. 2010, 132, 12859-12861. doi:10.1021/ja106257n

44. Troegel, B.; Lindel, T. Org. Lett. 2012, 14, 468-471. doi:10.1021/ol2029993

45. Peng, C.; Wang, Y.; Liu, L.; Wang, H.; Zhao, J.; Zhu, Q. Eur. J. Org. Chem. 2010, 818-822. doi:10.1002/ejoc.200901257

46. Li, H.; Yang, H.; Petersen, J. L.; Wang, K. K. J. Org. Chem. 2004, 69, 4500-4508. doi:10.1021/jo049716t

47. Oh, C. H.; Karmakar, S.; Park, H.; Ahn, Y.; Kim, J. W. J. Am. Chem. Soc. 2010, 132, 1792-1793. doi:10.1021/ja9106226

48. Sakai, N.; Annaka, K.; Fujita, A.; Sato, A.; Konakahara, T. J. Org. Chem. 2008, 73, 4160-4165. doi:10.1021/jo800464u

49. Murarka, S.; Studer, A. Angew. Chem., Int. Ed. 2012, 51, 12362-12366. doi:10.1002/anie.201206096

50. Swamy, N. K.; Yazici, A.; Pyne, S. G. J. Org. Chem. 2010, 75, 3412-3419. doi:10.1021/jo1005119

51. Arcadi, A.; Cacchi, S.; Marinelli, F. Tetrahedron Lett. 1986, 27 , 6397-6400. doi:10.1016/S0040-4039(00)87818-1

52. Liu, Q.; Chen, P.; Liu, G. ACS Catal. 2013, 3, 178-181. doi:10.1021/cs300733s

53. Engle, K. M.; Mei, T.-S.; Wang, X.; Yu, J.-Q. Angew. Chem., Int. Ed. 2011, 50, 1478-1491. doi:10.1002/anie.201005142

54. Wegner, H. A.; Auzias, M. Angew. Chem., Int. Ed. 2011, 50, 8236-8247. doi:10.1002/anie.201101603

55. Hopkinson, M. N.; Gee, A. D.; Gouverneur, V. Chem.-Eur. J. 2011, 17, 8248-8262. doi:10.1002/chem.201100736

56. Rudolph, M.; Hashmi, A. S. K. Chem. Commun. 2011, 47, 6536-6544. doi:10.1039/c1cc10780a

57. Garcia, P.; Malacria, M.; Aubert, C.; Gandon, V.; Fensterbank, L. ChemCatChem 2010, 2, 493-497. doi:10.1002/cctc.200900319

58. Ling, K.-Q. Synth. Commun. 1995, 25, 3831-3835. doi:10.1080/00397919508011457

59. Maeda, C.; Yoshioka, N. Org. Lett. 2012, 14, 2122-2125. doi:10.1021/ol300585v 
60. Slätt, J.; Bergman, J. Tetrahedron 2002, 58, 9187-9191. doi:10.1016/S0040-4020(02)01198-5

61. Ramana, C. V.; Patel, P.; Vanka, K.; Miao, B.; Degterev, A. Eur. J. Org. Chem. 2010, 5955-5966. doi:10.1002/ejoc.201000769 See for the formation of analogues of $\mathbf{9}$ during Pd- and Au-catalyzed cycloisomerization reactions of nitro-alkyne derivatives.

62. Asao, N.; Sato, K.; Yamamoto, Y. Tetrahedron Lett. 2003, 44, 5675-5677. doi:10.1016/S0040-4039(03)01357-1

63. Berti, C.; Colonna, M.; Greci, L.; Marchetti, L.; Perkins, M. J. J. Chem. Soc., Chem. Commun. 1981, 694-695. doi:10.1039/c39810000694

64. Rajawinslin, R. R.; Raihan, M. J.; Janreddy, D.; Kavala, V.; Kuo, C.-W.; Kuo, T.-S.; Chen, M.-L.; He, C. H.; Yao, C.-F. Eur. J. Org. Chem. 2013, 5743-5749. doi:10.1002/ejoc.201300599

65. Verniest, G.; Van Hende, E.; Surmont, R.; De Kimpe, N. Org. Lett. 2006, 8, 4767-4770. doi:10.1021/ol061720z

66. Surmont, R.; Verniest, G.; Colpaert, F.; Macdonald, G.; Thuring, J. W.; Deroose, F.; De Kimpe, N. J. Org. Chem. 2009, 74, 1377-1380. doi:10.1021/jo802272n

67. Surmont, R.; Verniest, G.; De Schrijver, M.; Thuring, J. W.; ten Holte, P.; Deroose, F.; De Kimpe, N. J. Org. Chem. 2011, 76, 4105-4111. doi:10.1021/jo2000989

68. Xu, T.; Liu, G. Org. Lett. 2012, 14, 5416-5419. doi:10.1021/ol3026507

\section{License and Terms}

This is an Open Access article under the terms of the Creative Commons Attribution License

(http://creativecommons.org/licenses/by/2.0), which permits unrestricted use, distribution, and reproduction in any medium, provided the original work is properly cited.

The license is subject to the Beilstein Journal of Organic Chemistry terms and conditions:

(http://www.beilstein-journals.org/bjoc)

The definitive version of this article is the electronic one which can be found at: doi:10.3762/bjoc. 10.42 